Article

\title{
Immigration and the Housing Market: The Case of Castel Volturno, in Campania Region, Italy
}

\author{
Fabiana Forte ${ }^{1}$, Valentina Antoniucci ${ }^{2, *}$ (i) and Pierfrancesco De Paola ${ }^{3}$ (D) \\ 1 Department of Architecture and Industrial Design, Università degli Studi della Campania "Luigi Vanvitelli", \\ Via S. Lorenzo ad Septimum, 81031 Aversa, Italy; fabiana.forte@unicampania.it \\ 2 Department of Civil, Environmental and Architectural Engineering, University of Padova, Via Venezia 1, \\ 35131 Padova, Italy \\ 3 Department of Industrial Engineering, University of Naples Federico II, Piazzale Vincenzo Tecchio 80, \\ 80125 Napoli, Italy; pierfrancesco.depaola@unina.it \\ * Correspondence: valentina.antoniucci@unipd.it
}

Received: 16 December 2017; Accepted: 26 January 2018; Published: 29 January 2018

\begin{abstract}
According to Eurostat, Italy is the fifth country of the European Union per immigrant population. The complexity of the phenomenon, as it has evolved in recent years, leads to analyzing it from a specific point of view, that of the real estate market. The article represents the early stage of research on the housing condition of the immigrant population in the Southern Italy and its effect on the housing market. First, we describe the spatial segregation phenomenon affecting the immigrant population in Campania Region; then we analyze data of the municipality of Castel Volturno, which has one of the greater migratory pressure throughout the whole region. We provide statistical regressions correlating housing prices and socio-economic features from 2006 to 2016. The results confirm the findings of the current literature on the subject: there is a specific phenomenon associated with the presence of an immigrant population residing in conjunction with a reduction of housing prices.
\end{abstract}

Keywords: housing market; multiple regression analysis; immigrants; spatial segregation

\section{Introduction}

Immigration, generally intended as the permanent or temporary moving of people to a country other than the country of origin, is a complex phenomenon characterized by multiple motivations and has historically affected several countries around the world. In Italy, which has traditionally been a country of emigration since Italy's unification, in the last fifteen years, there has been an intense increase in the flow of immigrants (according to Eurostat, on 1 January 2016, Italy is the fifth country of the European Union per immigrant population), resulting in economic, social and spatial problems. The complexity of the phenomenon, as it has evolved in recent years, leads to analysing it from a specific point of view, that of the real estate market [1-3]. From this point of view, an overview of immigrant housing conditions will be discussed, starting from the right to housing as well as recognized at international, European and national levels. An analysis of the housing market will follow, along with the living conditions of immigrants in Italy, examining the case of the Municipality of Castel Volturno in the metropolitan city of Naples, in Campania Region.

\section{The Right to Housing and Immigration}

As recognised in several international human rights treaties, housing is an "essential" right of every individual (see among others [4-6]).

First, the Universal Declaration of Human Rights (adopted by the United Nations General Assembly in 1948) in Article 25 recognises that "every individual has the right to a standard of living 
sufficient to guarantee his own health and well-being as well as that of his family with particular regard to the right to housing".

Subsequently, the UN International Covenant on Economic, Social and Cultural Rights (signed in 1966 but in force since 1976) states, in art. 1, that States recognise the right of the individual to an adequate standard of living, including housing, by committing the signatory States to take appropriate measures for this purpose. Furthermore, the Council of Europe's European Social Charter (drawn up in 1961, revised in 1996 and in force since 1999) commits States to take measures to ensure the active exercising of the right to housing (art.31).

Finally, the ILO Convention on Migrant Workers (1949) imposes on States the recognition of regularly non-resident foreign workers with a non-less favourable treatment of access to housing.

At a European Union level, the European Directive 2000/43/EC, implementing the principle of equal treatment between persons irrespective of racial or ethnic origin, states that this parity concerns "the access to goods and services as well as to their supply, including accommodation" (Article 31, h). In Italy, this Directive was transposed by DL 215/2003.

In addition, Council Directive 2003/109/EC on the status of third-country citizens who are long-term residents, with regard to equal treatment, provides that they enjoy the same treatment as nationals in the access to goods and services available to and from the public, as well as to the procedure for obtaining housing (Article 11, f).

In Italy, the right to housing, although not explicitly provided for by the Constitution, has repeatedly been referred to in several Constitutional Court (the highest Italian Court of Justice) rulings.

In general, the right of immigrants is governed by both immigration and housing legislation.

The "Unified Act of the Provisions on Immigration Rules and Standards on the Status of a Foreigner", introduced by DL No. 286 of 1998, aimed at promoting social integration by regions, provinces and other local authorities, in Chapter III sets out provisions on housing and social assistance. Article 40, paragraph 4, states: "Foreigners authorised to stay can access social, collective or private housing, prepared according to the criteria set out in the regional law, by municipalities of a larger settlement of foreigners or by associations, foundations or voluntary organisations or by other public or private organisations, in housing facilities, mainly in the form of boarding houses, open to Italians and foreigners, aiming to offer decent accommodation for reduced tariffs, while waiting to find definitive accommodation".

Subsequently, Law No. 189 of 2002 (the so called Bossi-Fini Law, Amendments to the Immigration and Asylum Act) amend some of the principles of the aforementioned Unified Act, stating that "immigrants holding a residence permit and foreigners regularly resident who have had a residence permit for at least two years and have a regular job or are self-employed, have the right, under conditions of parity with Italian citizens, to have access to public housing and brokerage agencies socially agreed upon by each region or local authorities to facilitate access to housing and credit facilities for the construction, recovery, purchase, and rental of a first house" (Article 27, Reception and Access to housing Centres).

With particular reference to the Campania Region, Law No. 6 of 2010 "Rules for the Social, Economic and Cultural Inclusion of Foreigners Present in Campania", art. 17, Access to Accommodation-Hostels, Social Housing, Public and Private Residential Buildings provides that the Region grant contributions to municipalities, provinces, institutions, foundations, associations and voluntary organizations that establish and manage reception centres, which develop or manage social housing, residences, and boarding houses with reduced tariffs.

In the framework of housing policies, with Resolution 356 of 2014, the Regional Council of Campania approved the Guidelines for the drafting and implementation of the Social Housing Construction Programs provided for by Article 10 of Law 80/2014 (Conversion, with modifications, of the decree-law of 28 March 2014 n. 47, Urgent Measures for the Housing Emergency, Construction Market and Expo 2015). As highlighted by the guidelines, Italian or EU member state citizens the European Union can access social housing, as well as non-EU citizens, wither holding a residence 
permit or resident who has had a residence permit for at least two years and has a regular job or is self-employed.

From this brief discussion on the regulatory framework of immigrant housing, there is still a substantial lack of specific policies for immigrants. It is possible to argue that, especially in Italy, there is no adequate social offer for the new issues that have emerged in recent times, in addition to those traditionally expressed by the weaker groups of the Italian population [7].

In Italy, compared with the more developed European countries, there is still: (a) a smaller consistency of private rented property since more than $70 \%$ of Italian households own the house in which they live; (b) one of the lowest shares of public housing; (c) a low supply of affordable social housing.

The housing poverty is particularly severe for the migrant population as well as ethnic minorities in general. In this case, in addition to economic-financial problems, access to housing is often hampered by forms of discrimination in the housing market that may be more or less pronounced.

In recent years, the migratory phenomenon is also having a significant impact at a territorial level: the absolute primacy of large urban centres is increasingly replaced by peripheral (or even rural) sites that, apparently, offer better opportunities regarding access to accommodation $[8,9]$.

About the Campania Region, a particularly important phenomenon for this study is represented by settlements in the hinterland of the larger cities, where the concentration (legal and illegal) of immigrants has grown exponentially.

The municipalities of Castel Volturno, in the province of Caserta (subject of the study) and S. Giuseppe Vesuviano (in the province of Naples) appear to be the two with higher migratory pressure throughout the whole region (see Table 1).

Table 1. Total of resident population, foreign residents and percentage of foreigners in the Campania Region and in the five provinces (ISTAT data 1 January 2016).

\begin{tabular}{cccc}
\hline City & Total Population (Provinces) & Total $\mathbf{n . ~ o f ~ F o r e i g n e r s ~}$ & \% Foreigners \\
\hline & $\mathbf{5 , 8 5 0 , 8 5 0}$ & $\mathbf{2 3 2 , 2 1 4}$ & $\mathbf{4 . 0}$ \\
\hline Avellino & 425,325 & 12,449 & 2.9 \\
Benevento & 280,707 & 7503 & 2.7 \\
Caserta & 924,414 & 43,439 & 4.7 \\
Castel Volturno & 25,281 & 3880 & 15.3 \\
Napoli & $3,113,898$ & 117,825 & 3.8 \\
S. Giuseppe Vesuviano & 30,657 & 4517 & 14.7 \\
Salerno & $1,106,506$ & 50,998 & 4.6 \\
\hline
\end{tabular}

As documented by numerous studies and reports, although immigrants nowadays represent a stable segment of the housing market (in terms of both sales and renting), it can be argued that in the Campania Region the housing problem for immigrants is still widespread, due to both the evident (now structural) imbalance between demand and supply, with significant consequences on selling prices and rental rates, as well as the precariousness of the legal and working status of immigrants [10].

\section{The Housing Market and the Living Conditions of Immigrants in Italy}

After a long and steep descent determined by the economic crisis, registered throughout the country since 2007, nowadays the housing market seems to have started to grow in recent years (see Figure 1). 


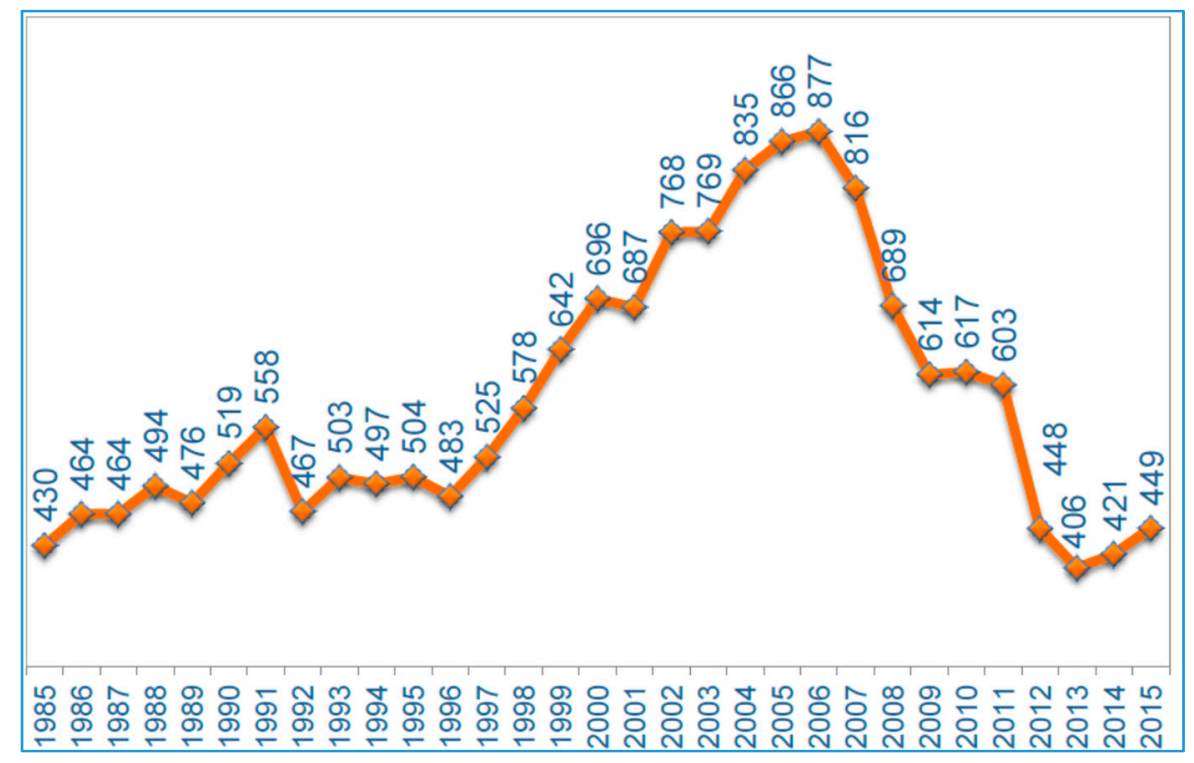

Figure 1. Residential property market, sales trend for the period 1985-2015 (source: OMI, Property Report, Residential Sector, 2016).

Among the determinant factors for the recovery, it is worth considering the following: the overall economic situation that begins to give signs of recovery, which are reflected on the indicators that measure the confidence of Italian households specifically; reduced interest rates and rising bank credit; the further fall in house prices which disincentives the "delay" to purchasing [11].

In this scenario, the recovery of the housing market is not only determined by the purchases of Italian families, but also by the investments made by immigrants living and working in Italy. According to the "Immigrants and Houses" Report [12], first-time home purchases in the year 2015 rose by 8.3\%, for a total value of $€ 3.8$ billion euros $(+15 \%)$, as shown in Table 2 . The share of housing transactions made by immigrant population accounts for $8.7 \%$.

Table 2. Time series of the housing purchases made by immigrants for the period 2006-2015.

\begin{tabular}{cccccc}
\hline Year & Index 2006 $\mathbf{1 0 0}$ & $\begin{array}{c}\text { Purchases } \\
\text { (No.) }\end{array}$ & $\begin{array}{c}\text { Variation } \\
\text { per Year (\%) }\end{array}$ & $\begin{array}{c}\text { Total Value } \\
\text { (Million Euros) }\end{array}$ & $\begin{array}{c}\text { Variation per } \\
\text { Year (\%) }\end{array}$ \\
\hline 2006 & 100.0 & 13,100 & 12.90 & 15,300 & 27.50 \\
2007 & 103.0 & 13,500 & 3.10 & 16,800 & 9.80 \\
2008 & 78.6 & 10,300 & -23.70 & 11,700 & -30.40 \\
2009 & 57.3 & $75,000.00$ & -27.20 & 8600 & -26.50 \\
2010 & 42.8 & $56,000.00$ & -25.30 & 6000 & -30.20 \\
2011 & 38.2 & $50,000.00$ & -10.70 & 5200 & -13.30 \\
2012 & 35.9 & $47,000.00$ & -21.70 & 4700 & -24.20 \\
2013 & 30.5 & $40,000.00$ & -14.90 & 3900 & -17.00 \\
2014 & 27.5 & $36,000.00$ & -10.00 & 3300 & -15.40 \\
2015 & 29.8 & $39,000.00$ & 8.30 & 3800 & 15.10 \\
\hline
\end{tabular}

Source: Scenari Immobiliari, 2016.

The housing units are usually not very large (about 90 square metres), not new or high-quality constructed, in peripheral or non-central urban areas (37\% of the cases) or small municipalities in the province (almost $50 \%$ of the cases).

The locations of the purchased housing units are mainly in peripheral $(36.7 \%)$ and provincial areas $(50.1 \%)$, characterized by a broader offer and affordable prices, compared to the larger urban and metropolitan areas (see Figure 2, Source: Scenari Immobiliari, 2016). 


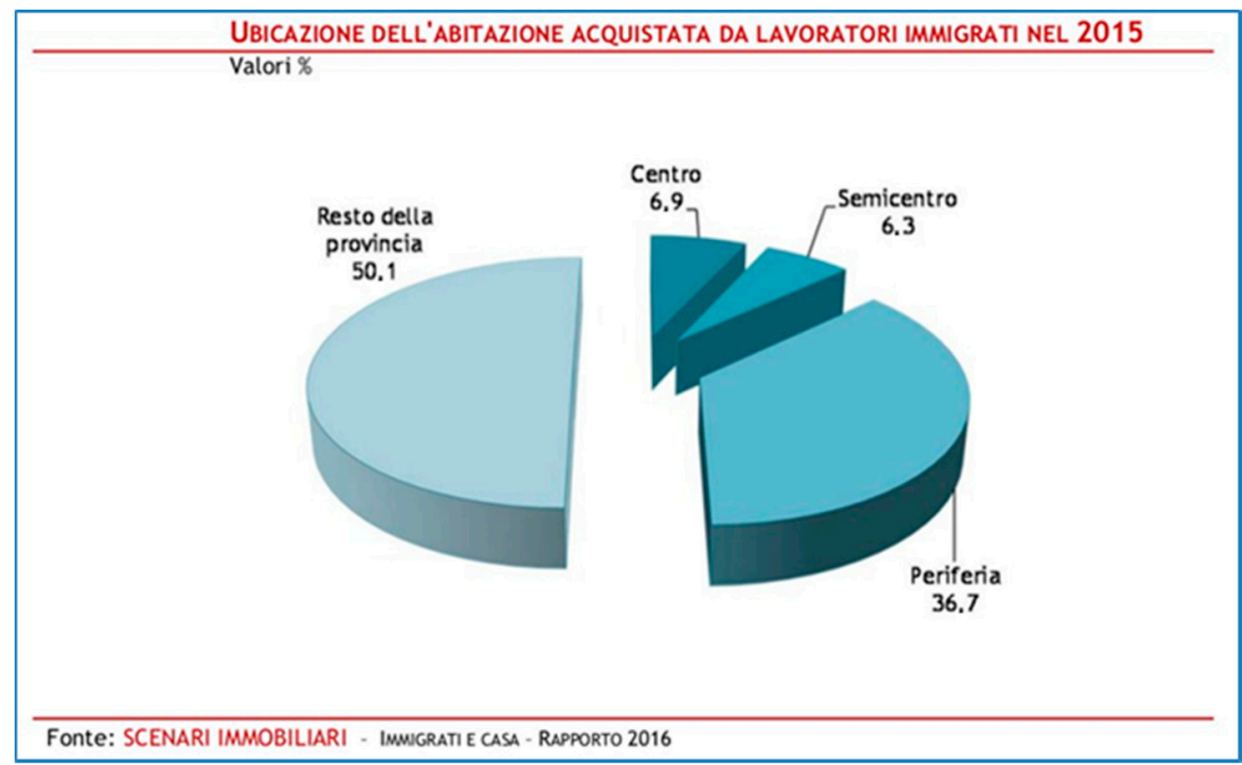

Figure 2. Locations of the housing purchased by immigrants in 2015.

According to the "Immigrants and Houses" report, notwithstanding the recovery due to immigrants buying houses, most of the foreigners in Italy live in rented accommodation $(62.8 \%)$ and tend to stay in communities with their fellow nationals, for as long as their stay is temporary.

It is also worth noting how $19.1 \%$ live in what is theirs, $9.8 \%$ live with others (relatives or other nationals), and $8.3 \%$ live in the place where they work.

As highlighted by the "Immigration Statistics Dossier 2016" by IDOS [13] immigrants are also more exposed to the risk of being evicted since they have more contact with the rental market. Even if the trend of evictions in 2015 slightly improved compared to the previous year.

The largest number of evictions is in the regions with the higher number of immigrants, such as Lombardy, Lazio, Emilia Romagna, Campania, and Tuscany.

The most common cause of evictions is rent arrears and regards immigrants mostly, who are often employed in low-paid jobs and more likely to lose their jobs.

Several studies carried out on housing selling prices, both sales and rental (agencies and ads.), highlight the persistence of discriminatory attitudes by owners towards immigrants looking for a house [14-16].

These data confirm the international literature on the topic. Spatial segregation is discussed on a twofold approach: on the one hand, literature analyses the immigrants' tendency to reside where their ethnic group is more concentrated, as this improves their chances of sharing knowledge, job opportunities, and customs [17]. On the other hand, spatial segregation also correlates closely with less skilled jobs and lower wages [18,19]. Planners have also discussed how the structure of a city may influence spatial inequality, with mostly conflicting results. While scholars following neoclassical economic theory disregard urban form—and urban density versus sprawl in particular [20] - as a possible cause of racial or ethnic segregation [21,22], others see sprawl as a driver of inequality and segregation in metropolitan areas. Also, Western US city centers are characterized by income and racial segregation due to the high car-dependency and limited public transports in metropolitan areas (for instance, see $[23,24]$ ).

Foreign-born resident clustering is strongly associated with local housing market trends. As in the labor market, Saiz [25] estimated that, in U.S. "gateway" cities, a 1\% increase in median housing rents and prices was associated with a $1 \%$ immigration inflow into a city's population. Saiz ([25] p. 346) found "a very robust impact on rents and housing prices that is an order of magnitude bigger than the estimates from wages literature". 
Empirical studies on the impact of immigration on housing prices in Europe are less developed. Gonzales and Ortega [26] measured the correlation between the housing market boom in Spain (2000-2010) and the rising of immigration. Furthermore, a 2.7\% growth in housing prices in Switzerland is correlated with a $1 \%$ growth in the immigrant population, despite a flat market and a low level of immigration [27]. On the contrary, others identified in the UK a negative correlation between immigration and housing prices due to the mobility of the native population facing foreign resident's concentration [28].

Finally, it is appropriate to highlight the findings of the study published by the Bank of Italy, "Don't stand so close to me: the urban impacts of immigration" [29], which analysed housing prices in the 20 cities where about one-quarter of the total immigrant population is present.

As highlighted by a summary of the study, between 2000 and 2010, there was a significant increase in migration flows from the poorest to the most economically developed countries, which mainly affected urban areas. In the cities, immigrants tend to concentrate in certain areas: this phenomenon is also evident in Italy, where the number of immigrants in some neighborhoods is about ten times higher than the corresponding number in other neighborhoods. Therefore, the study analyses the interaction between natives and immigrants in Italian urban areas, examining the effects of a foreign presence on the housing market.

The analysis is based on a theoretical model in which it is assumed that immigrants have on average lower incomes than natives and that the latter may change neighbourhood following the influx of immigrants. The greatest demand for housing associated with rising immigrants in a neighbourhood causes a rise in average house prices throughout the city. If, as a result of immigration, natives also perceive a deterioration in the quality of life, for example because they involve a possible worsening of services offered (such as crowding in public transport), then the prices rise less in the neighbourhood where there is a greater immigrant concentration than the average price rising within the whole city. This phenomenon is also associated with their outflow into other areas of the city. The effects are of opposite significance if the presence of foreigners is positively influencing the prospects for quality of life (for example through a greater variety of goods and services offered).

The hypotheses of the authors [29] are tested through empirical evidence using a data sample, related to the period 2013-2010, of 20 Italian cities, in which about one-quarter of the total immigrant population is concentrated. An increase of $10 \%$ of the foreign population in a neighbourhood corresponds to the $1.6 \%$ rising of the average housing prices at urban level; the price change is almost nothing in the areas where foreigners are concentrated and the highest in the rest of the city.

The study highlights how the arrival of immigrants is perceived as a deterioration of the quality of life of a neighbourhood. While on the overall urban level, the increase in housing demand creates a rise in prices, in the neighbourhood where the foreign community settles, the increase is less significant. The authors also point out that such dynamics are consistent with US dynamics of urban segregation, even though Italians tend to refuse immigrants as their neighbours more than in the US.

Finally, luxury properties tend to have a higher price than average properties due to immigration, because, as the study explains, the demand for prestigious homes becomes higher, with it becoming a way to create a distance from the perceived urban deprivation related to the quality of life in the immigrant's most populated urban area.

These results are also confirmed by other recent empirical research conducted in Italy, specifically on sample prices of Italian provincial capitals. In one case, the authors demonstrate the relevance of urban density on the increase of social polarisation within the cities [30] on the relationship between housing prices gradient and, moreover, they highlight the correlation between housing prices gradient and the share of the immigrant population within and between cities [31]. 
The Housing Market in Campania and Immigration

The housing market in Campania is highly segmented, with a variety of property contexts, where the price gap is somewhat accentuated, with an apparent dichotomy between the provinces of Avellino and Benevento and the other three on the sea, Naples, Caserta, and Salerno.

According to the latest available data [32], the property market in Campania is recording signs of recovery, although transaction volumes remain at shallow levels; Campania is the most expensive region in the south, even though with a price level below the national average.

The Italian Revenue Agency [33] confirms that in the first half of 2016, the number of housing units' sales grew by more than $18.0 \%$ over the corresponding period of 2015 . This increase is related mostly to the three coastal provinces [34].

Regarding the rental housing market in Campania, according to the Rent Report 2015 by Solo Affitti [35], drawn up with the scientific support of Nomisma, almost one out of five houses is empty (17.08\% for 417,576 empty homes) the majority of which is in the provinces of Avellino and Benevento. The percentage of vacant properties in the provinces of Caserta (at third place at regional level with $21.72 \%$, and 88.609 properties unoccupied), Salerno (at the fourth place with $21.44 \%$, and 108.124 empty houses) and Naples (at the last place with $11.02 \%$, and 128,976 unoccupied housing units) are under the national average (22.55\%).

In general, in Campania, the number of immigrants experiencing a housing problem is relatively high. This is a mainly urban/metropolitan phenomenon since the immigrant concentration is consolidated in the fringe and marginal locations of the large metropolitan area that goes from Caserta to Salerno via Naples. Here the phenomenon of housing poverty reaches the greatest intensity by creating extreme conditions of spatial segregation.

As highlighted by Ammirato et al. [10], a large proportion of the immigrant population in the Region does not own a housing unit, and the widespread housing conditions involve living with others.

According to this study, based on a sample related to 2013, the percentage of immigrants owning a house was only $3.5 \%$, far below the $19.1 \%$ average data at national level. Moreover, the $54.5 \%$ of immigrants live in rented accommodation with a regular contract, while $21.1 \%$ live in rented accommodation with informal solutions.

Housing deprivation is also pronounced in rural areas where, however, there is higher availability of space and a higher number of residential units that, even if in poor conditions, are a better solution than living in makeshift shelters. This is the case of the Nocerino/Sarnese area, Agroaversano area, and the Domitian coast where the illegal and informal use of holiday homes by immigrant population results mostly in a situation of severe social tension [36].

\section{The Case of Castel Volturno: The Urban Framework}

The municipality of Castel Volturno, in the province of Caserta, begins at the mouth of the river Volturno and extends over an area of $72.23 \mathrm{~km}^{2}$. The territory is crossed throughout its length by the Domitiana road, which divides it into two distinct parts: a coastal area with tourist and commercial activities, and the other with an economy linked mainly to the farming and breeding of "Bufale" cows, which is local excellence in the primary sector.

The urban structure (see Figure 3) is very fragmented due to the presence of different locations such as the Historical Centre, Scatozza, Baia Verde, Villaggio del Sole, Mezzagni, Borgo Domitio, Villaggio Coppola, Ischitella, Dx Volturno, Mazzafarro, Pescopagano, Bagnara and Seponi.

The original nucleus of inhabitants of Castel Volturno, the smaller group to date, has been joined by nomadic families and, from the 1960s onwards, by heterogeneous groups of citizens in an ever-increasing number, reaching its peak in the 1980s-1990s, following the earthquake in the 1980s and the bradyseism in Pozzuoli area. In recent years, the presence of non-EU citizens has intensified, coming mainly from Africa (mainly from Nigeria), the Orient and East European (especially from Ukraine) who usually live in this vast and unsafe area, as it is described below. 


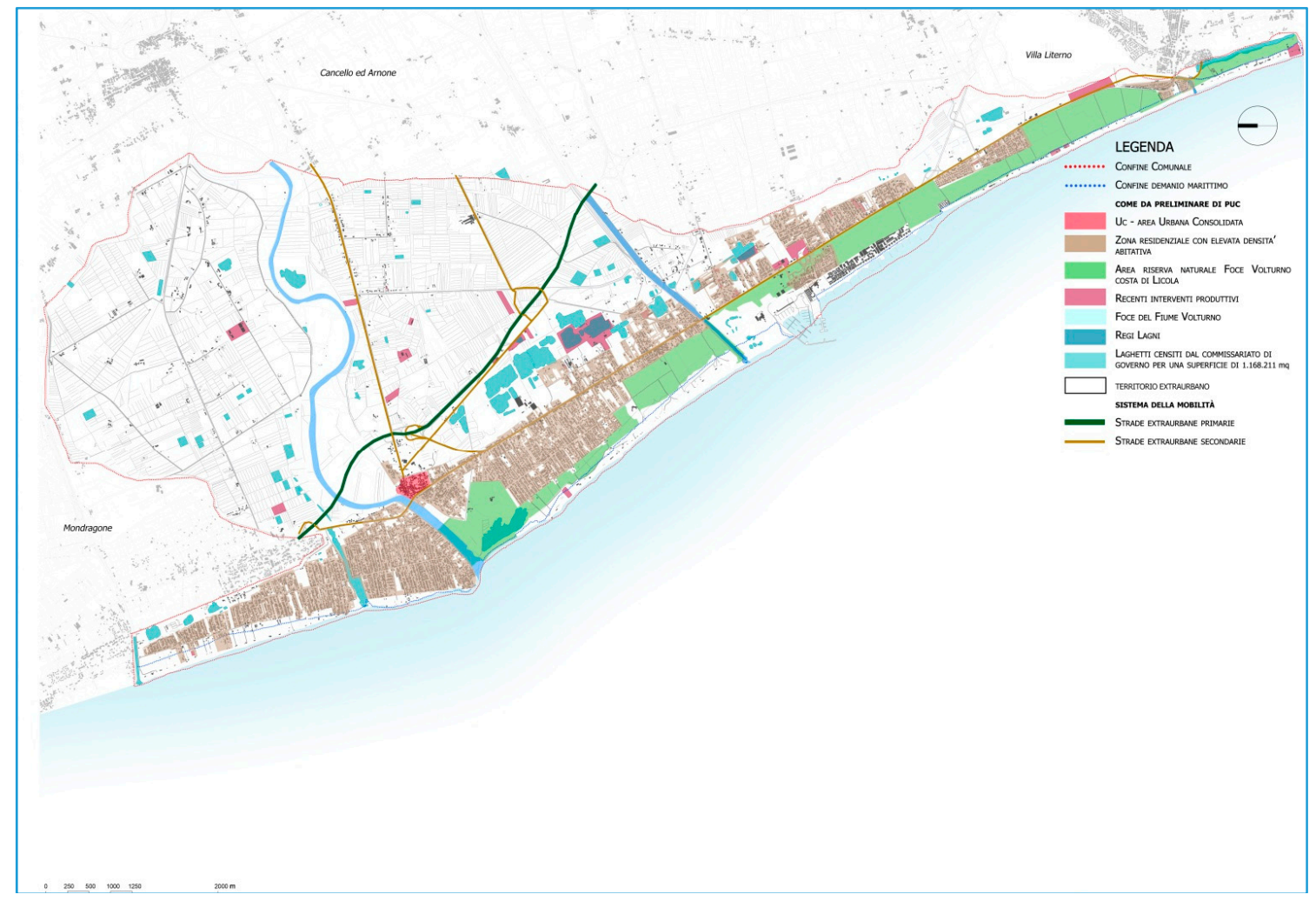

Figure 3. Municipality of Castel Volturno, (Source: Somma, master degree thesis, 2017 [37]).

According to ISTAT (Italian Institute of Statistics) data, there has been a positive demographic trend since 1971 (see Table 3).

Table 3. Demographic trends of the Municipality of Castel Volturno (Source: ISTAT).

\begin{tabular}{ccccccc}
\hline 1971 & 1981 & 1991 & 2001 & 2011 & Var 01/11 & 2016 \\
\hline 3.661 & 7.311 & 15.140 & 18.639 & 22.882 & $22 \%$ & 25.281 \\
\hline
\end{tabular}

Over the past 40 years, demographic growth is accountable only partially to a positive natural balance, since the number of immigrants is significant, with an ever-positive migratory balance, as can be seen from Table 4, which represents in detail the period 2006-2016.

Table 4. Population trends over the period 2006-2016 in Castel Volturno (Source: ISTAT).

\begin{tabular}{ccc}
\hline Year & $\begin{array}{c}\text { Immigrant } \\
\text { Population (No.) }\end{array}$ & $\begin{array}{c}\text { Share of Immigrants on the Total } \\
\text { Amount Population (\%) }\end{array}$ \\
\hline 2007 & 2083 & 9.29 \\
2008 & 2303 & 10.10 \\
2009 & 2376 & 10.09 \\
2010 & 2512 & 10.52 \\
2011 & 2933 & 12.15 \\
2012 & 3071 & 13.39 \\
2013 & 3415 & 14.82 \\
2014 & 3568 & 14.61 \\
2015 & 3854 & 15.30 \\
2016 & 3880 & 15.35 \\
\hline
\end{tabular}


The population growth is at a steady pace, but there is also a considerable increase in the percentage of resident immigrants, which was just over $9 \%$ of the total population in 2006 and became over $15 \%$ in 2016.

This figure is more than three times the average provincial incidence of the immigrant population in the same period (Source: ISTAT, Municipalities-Italians), which is between 5\% and $6 \%$ of the total population. It is also worth noting how the evolution of the officially registered population cannot take into account the illegal immigrant population, which also resides along the Domitian coast, and is employed mainly in the primary sector, even seasonally. Therefore, it is reasonable to assume that the overall incidence of the immigrant population on the total population is even higher and occupies the proportion of the most poor-quality building stock, in terms both of building quality and urban environments.

From the housing characteristics, only the historic centre and Villaggio Coppola have a large population, the rest is scattered throughout the various villages, especially along the Domitian coast, where the phenomenon of illegal buildings is particularly accented [38]. Unfortunately, the distribution of the immigrant population in the diverse neighbourhoods is not available, as it is for housing prices instead, because the population data are clustered as native and foreign residents.

The quality of housing stock varies significantly from the historic centre to the Coast. In the historic centre, there are old and new buildings, while along the coast, the urban context is mostly residential, but nowadays in poor conditions and occupied illegally by economically disadvantaged families. The remaining part of poor-quality and abandoned buildings are empty.

The "patchy" distribution of the population throughout the territory, its varied origins, the considerable mobility, internal and external of the population, the trouble and unsafety with which this appropriation took place, and the problems that triggered this condition has made Castel Volturno a "difficult" area to interpret and manage, as various studies have highlighted $[39,40]$.

The dynamics of the population described above are reflected in the housing supply. The data collected by ISTAT at a ten-year rate in the Population and Housing Census show that much of the residential building stock, equal to $60 \%$ of the total was built between 1971 and 1990, when in the previous nine years, from 1961 to 1970 , nearly $28 \%$ of the existing housing units was realised [41].

Out of 13,571 buildings, mostly residential, corresponding to $94 \%$ of the total buildings, 8,939 buildings were constructed between 1971 and 1990, while 3751 housing units were built between 1961 and 1970 (see Figure 4).

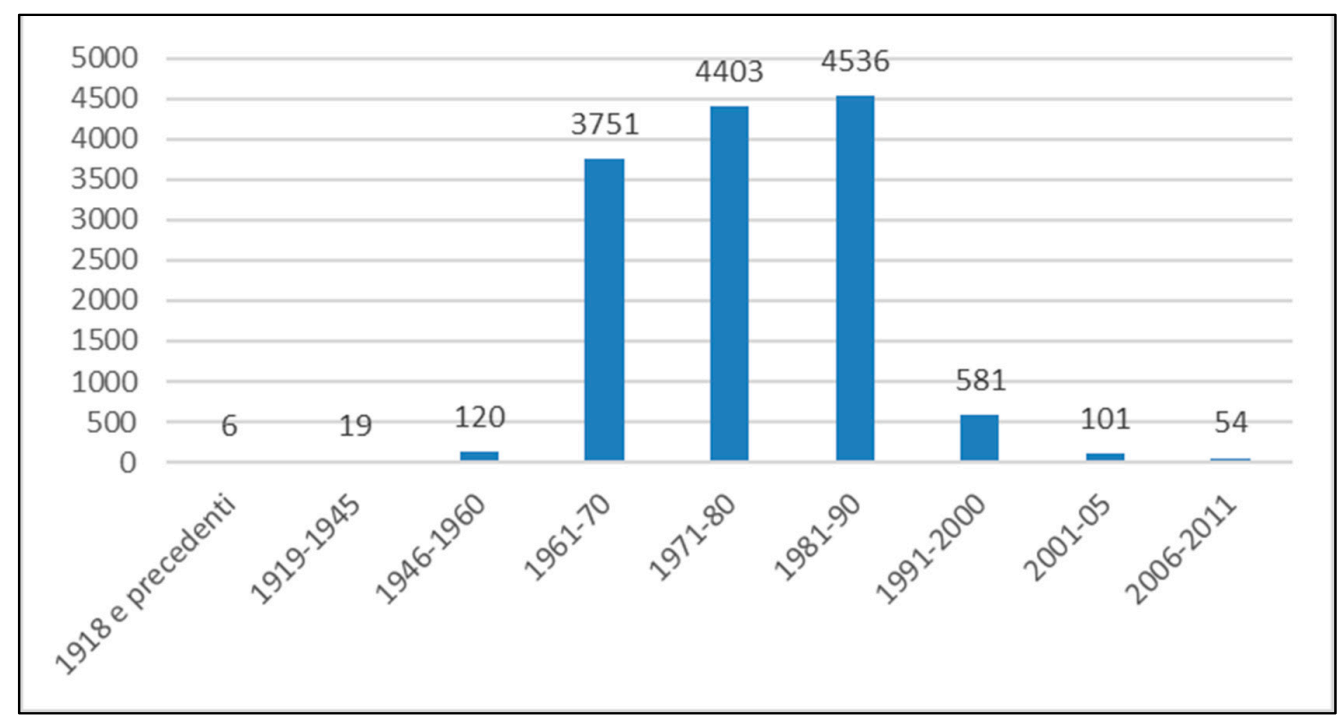

Figure 4. Number of residential buildings by construction period in Castel Volturno (Source: ISTAT, 2016). 
It is worth noting how the historic building stock is particularly limited as well as the recent and most recent constructions, with a consistency of just over 1\%. Most of the housing stock is therefore between 45 and 30 years old: the age of buildings is one of the main features explaining the poor price dynamic in the area [42-44].

There may be more than one reason for the low incidence of the recent and more recent housing. On the one hand, it can be caused by an excess of supply during the economic boom years, also due to the development of holiday-homes, as well as the internal migratory dynamics due to of the seismic phenomena. While, on the other hand, there is a structural weakness in the demand for quality properties, due both to the increase in the immigrant population, characterised by a modest spending capacity and the generalised crisis of the local economy.

It is also worth recalling that the average employment rate in the province of Caserta has fallen from $43 \%$ in 2006 to 38\% in 2016 (Source: ISTAT, 2016), while the average per capita income in the municipality of Castel Volturno has fallen to levels prior to 2008 (see Figure 5; Source: Ministry of Economy and Finance).

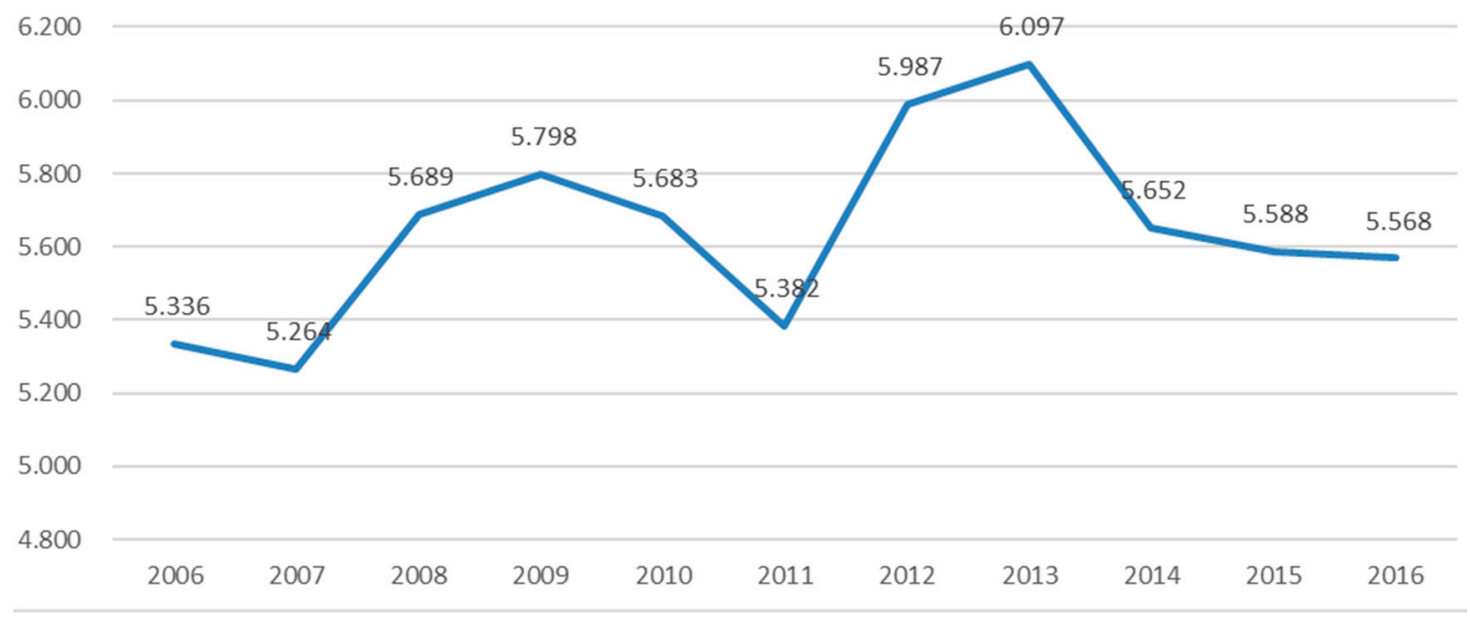

Figure 5. Per capita income trend in the municipality of Castel Volturno; Period 2006-2016 (current currency).

\subsection{The Local Housing Market}

The study of the local residential property market [45-47] starts with the analysis of the housing prices' trend in the municipality of Castel Volturno, provided by the Observatory of the Property Market (OMI), of the Italian Revenue Agency (We would like to thank the Italian Revenue Agency and, in particular, the Management of the Central Observatory Property Market Appraisals Services for providing the data), which registers the minimum and maximum prices of residential, commercial and productive properties (if present) per unit $\left(E u r o / \mathrm{m}^{2}\right)$ of each micro-zone per half-year.

The locations and building quality features (accessibility, public and private services, quality of public space and building typology), which correspond to various property values.

The present analysis regards only the housing prices. The data are further differentiated according to the different buildings typology and quality such as civilian homes, apartments, villas, and bungalows. Since the sample is structured based on a ten-year historical period, referring to the period 2006-2016, only the average values recorded for each micro zone (It should be noted that the micro-zones do not necessarily coincide with the cadastral micro-areas) are used (see Figure 6).

The housing prices at the urban level are consistent with the national trend: the period 2006-2008 represents the last stage of growth of the boom period began in 1996-1998, which recorded a global expansion of the property market, regarding both demand and prices. 


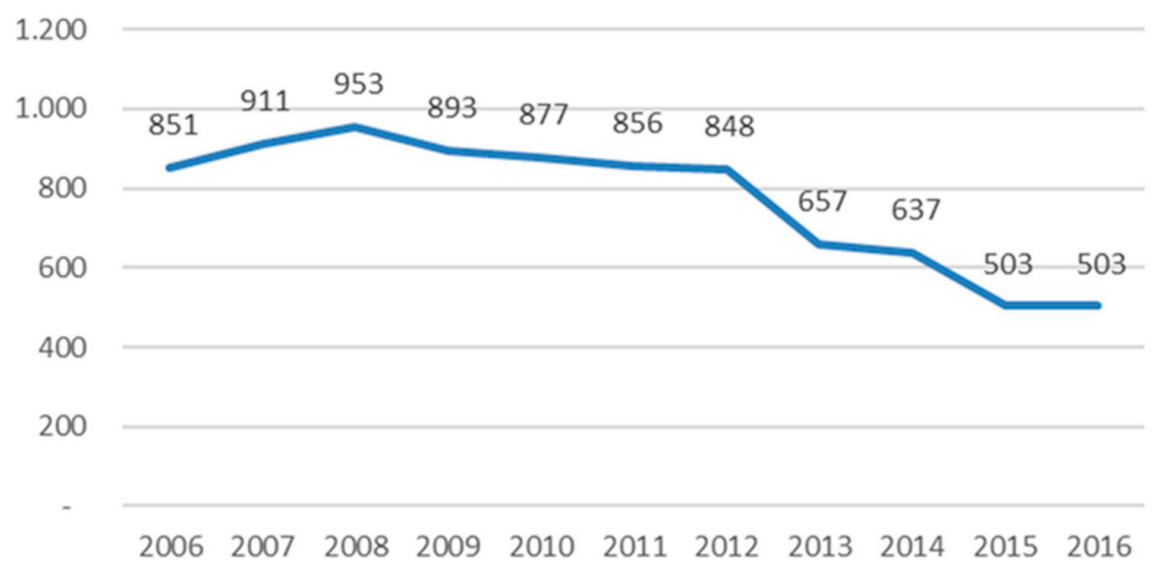

Figure 6. Evolution of average residential prices (Euro/sqm) in the Municipality of Castel Volturno; Period 2006-2016 (Source: Territorial Agency, OMI).

In Italy, although consistent with the general trend, the "property bubble" did not develop, unlike more volatile markets such as North America, from 2008 to date, there has been a continuous decrease of the prices, coupled with a significant reduction in demand with two peaks marking a worsening of the trend: in 2008, following the global financial crisis of 2007 [48] and 2012, following the sovereign debt crisis in Italy in 2011: from 2008 to 2012 prices declined until recently below the levels of 2006, while from 2012 to today, the housing prices recorded a collapse of more than $40 \%$ (see Figure 7).

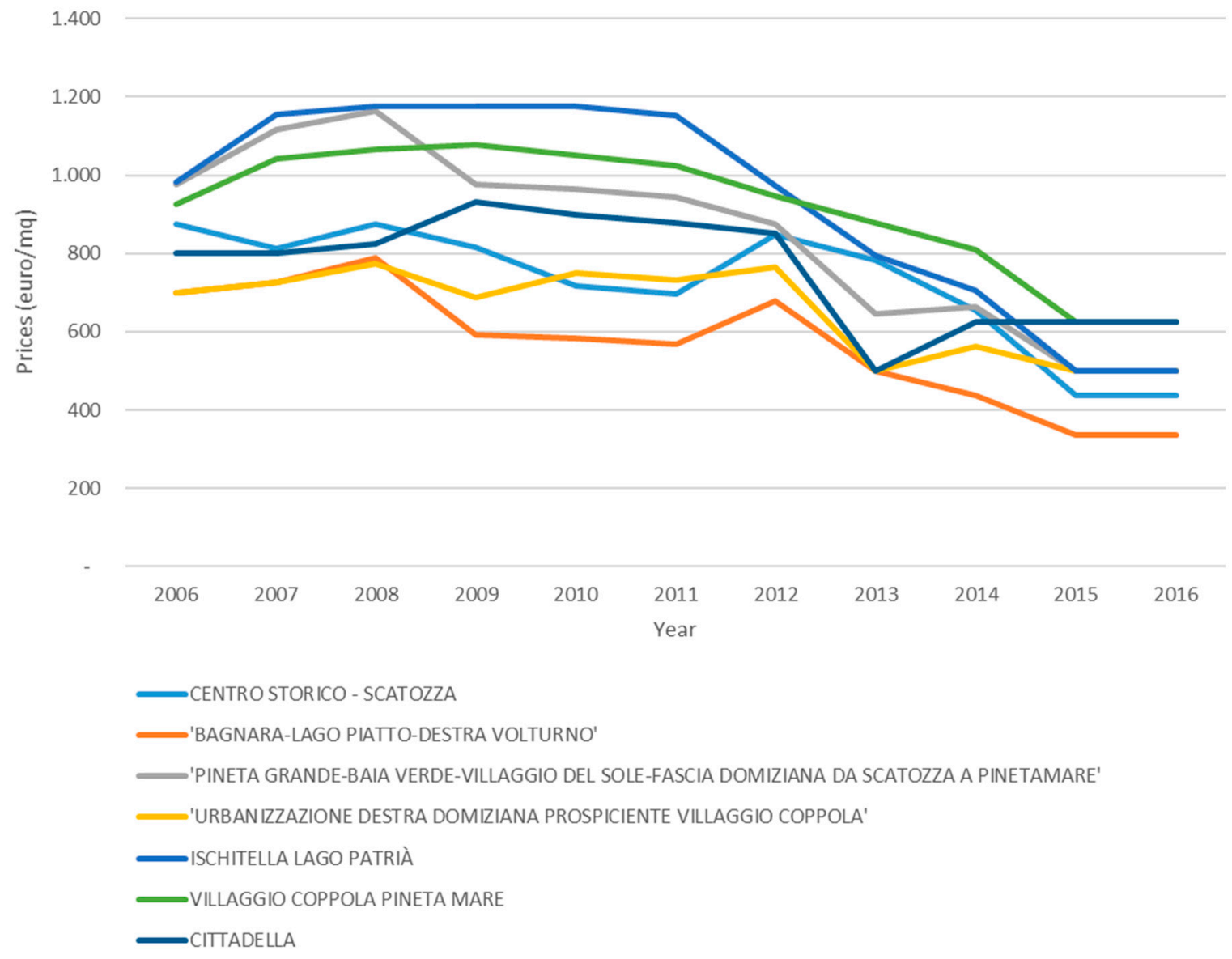

Figure 7. Trend of the housing prices in the micro-zones of Castel Volturno (2006-2016). 
By analysing the residential prices at the local scale, it is worth noting how the trend described is differentiated by areas up to the period 2008-2009, when the areas of "Ischitella-Lago Patrià" and from "Pineta Grande to Pineta Mare" show a better hold about the others. In the two-year period 2012-2013, however, all the areas have a marked contraction of prices with a collapse recorded in the developments to the right of the Domitiana, Bagnara, Lago Piatto, Destra Volturno, and finally the Historic Centre, and Scatozza.

\subsection{The Importance of the Immigrant Population on the Local Residential Market Trend}

The examination of the local property market and the analysis of the socio-economic characteristics of Castel Volturno give useful indications on the context of the investigation but do not allow to hypothesize scientifically founded correlations or even infer from causal relationships between the various factors affecting the housing market [49-51].

Therefore, a series of multiple and simple regression was carried out to identify the statistically significant correlations between the average housing prices and the socio-economic characteristics of the urban area described above.

The dependent variable $(\mathrm{y})$ is represented by the trend of average prices in the residential sub-market during 2006-2016, while the independent variables (x1, x2, x3) are:

- $\quad$ average per capita income over the period 2006-2016 (Euro);

- immigrant population, resident in the period 2006-2016 (n.);

- $\quad$ population density $\left(\mathrm{ab} / \mathrm{km}^{2}\right)$.

While per capita income is a recognized feature affecting prices' trend, we also consider population density to verify whether urban form may affect the trend of prices. It was not possible to test other collected data since they were either only available for a single-year or because they are static and non-dynamic data and, ultimately, because they are not available at the neighborhood scale. These are:

- $\quad$ administrative area of the municipality $\left(\mathrm{km}^{2}\right)$;

- employment rate;

- gross domestic product;

- buildings divided by construction period.

The results of the simple regression show a strong negative correlation between the trend of average prices of the residential sub-market and the trend of immigrant population. Data are tested for each year from 2006 to 2016. As the resident immigrant population increases, there is a decrease in average housing values (see Figure 8).

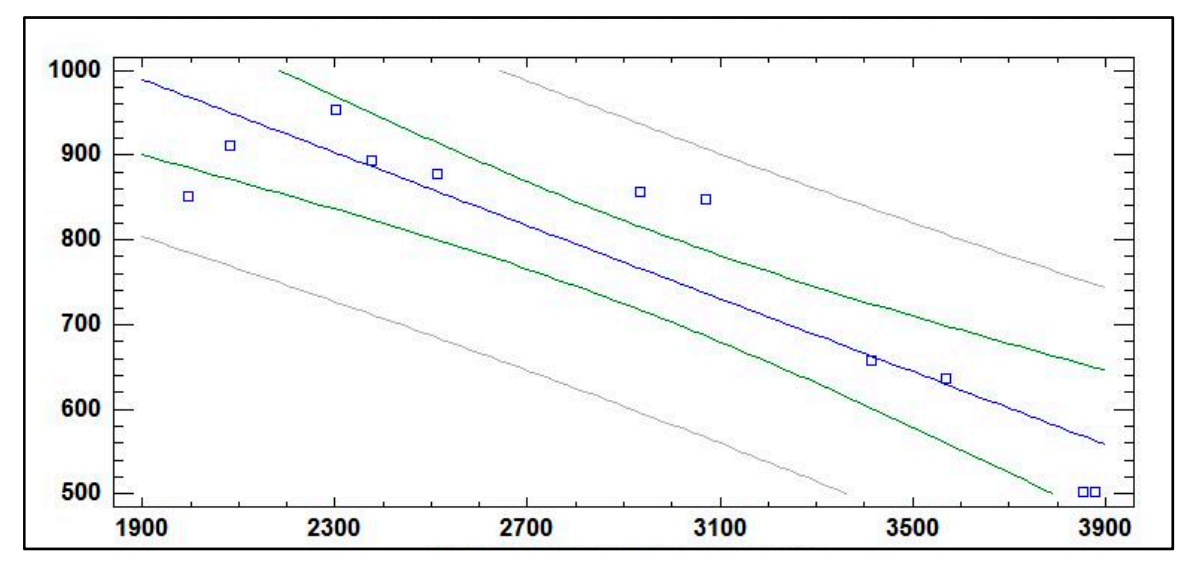

Figure 8. Trend of the regression line relative to average unit market values ( $€ /$ sqm) $(Y)$ and the trend of immigrant population (No.) (X). 
The degree of adaptability of the model is particularly high, equal to $81 \%$ (see Table 5): the adjusted R2 represents the reliability of the statistical model—therefore of the estimated values-compared to the actual prices recorded.

Table 5. Results of the simple statistical regression (data since 2006 to 2016).

\begin{tabular}{ccccc}
\hline & Coef. & Std. Error & T-Value & $p$-Value \\
\hline Constant & 1398.27 & 97.2672 & 14.3755 & 0.0000 \\
Trend of Immigrant population (2006-2016) & 0.21539 & 0.0326013 & 6.60681 & 0.0001 \\
\hline
\end{tabular}

Note: Dependent variable: Trend of average market values since 2006 to 2016 (euro/sqm), Independent variable: Trend of immigrant population since 2006 to 2016 (No.), $R^{2}=\mathbf{8 2 . 9 1 \% ,} R^{2}$ adj. $=\mathbf{8 1 . 0 1 \%}$, Standard Error $=\mathbf{7 2 . 0 0}$, $\mathrm{MAE}=\mathbf{5 2 . 0 2}$.

This is a particularly robust result when considering the use of only one variable to explain possible correlations with such a varied phenomenon as the property market as a whole.

It is also worth highlighting how a variable such as average per capita income is not statistically significant. This is particularly singular considering that spending capacity is one of the components that traditionally have a greater impact on demand and prices.

After the analysis of housing trends within the municipality, we test the potential diverse incidence of the immigrant population among the portions of urban territory in the last ten years.

The outcomes confirm the generalised model, with the high statistical significance of the results. For each homogeneous area, except for "Cittadella", the adequacy of the model is over 50\%: the areas where the negative correlation between the trend in housing prices and the immigrant population is higher are "Ischitella-Lago Patrià" and "Villaggio Coppola-Pineta Mare", whereas in one case, along the "Domitian coast from Scatozza to Pineta Mare", the correlation is positive, i.e., an increase in the immigrant population leads to an increase in the unit values (see Table 6).

Table 6. Results of the statistical regression of the unit market values' trend (Y)—the immigrant population's trend (X) (2006-2016).

\begin{tabular}{ccccc}
\hline Neighbourhood & Intercept & Coeff. & $\begin{array}{c}\text { Correlation } \\
\text { Coeff. }\end{array}$ & $\mathbf{R}^{2}$ adj. \\
\hline Centro Storico-Scatozza & $1256.94^{*}$ & $0.18357^{*}$ & -0.808475 & $61.51 \%$ \\
\hline Bagnara_Lago Piatto-Destra Volturno & $1134.03 *$ & $-0.19485^{*}$ & -0.890703 & $77.04 \%$ \\
\hline $\begin{array}{c}\text { Pineta grande-Baia verde-Villaggio del } \\
\text { sole-Fascia domiziana da Scatozza a Pinetamare }\end{array}$ & $251.759 * *$ & $0.55620 *$ & 0.818874 & $63.40 \%$ \\
\hline $\begin{array}{c}\text { Urbanizzazione destra domiziana prospiciente } \\
\text { Villaggio Coppola }\end{array}$ & $1037.84 *$ & $-0.13186 *$ & -0.807463 & $61.33 \%$ \\
\hline $\begin{array}{c}\text { Ischitella-Lago Patrià } \\
\text { Villaggio Coppola-Pineta Mare }\end{array}$ & $1911.85^{*}$ & $-0.33589 *$ & -0.872273 & $73.43 \%$ \\
\hline Cittadella & $11801.38^{*}$ & $-0.20140 *$ & -0.844132 & $68.06 \%$ \\
\hline Note: ${ }^{*}$ means $p$-value $=99 \%, * *$ means $p$-value $=95 \%$. & $0.14701 * *$ & -0.723919 & $47.12 \%$ \\
\hline
\end{tabular}

\section{Conclusions}

Even though the analysis does not allow to hypothesise any causal relationships between the variables, nor have a predictive character, because of the wide variety of micro-economic factors affecting price variation, it is evident in this case that the urban scale demographic composition has a significantly higher relevance to income which, even on municipal level, is characterized by greater homogeneity than the immigrant population component, far greater than the average at provincial scale. 
The importance that the immigrant population assumes in the trend of housing prices, since 2006 to 2016, in the municipality of Castel Volturno confirms the findings of the current literature on the subject: there is, therefore, a specific phenomenon associated with the presence of an immigrant population residing in conjunction with a reduction of housing prices.

In the territorial context under investigation there are specific, and almost unique, socio-economic conditions that over time have induced the local real estate market to be completely avulsed from macroeconomic dynamics.

More in detail, the deep-rooted presence of organized crime, the waste abandonment, the presence of toxic waste buried underground by organized crime, the urban and environmental degradation, the extensive illegal buildings (see Figures 9 and 10), they are all features that have favored the massive increase of immigrants in Castel Volturno (legal and illegal). It is estimated that, in 2016, in the municipality of Castel Volturno there are at least 15,000 permanently resident illegal immigrants, a number four times higher than the number of legal immigrants for the same year (Source: www. napoli.repubblica.it).

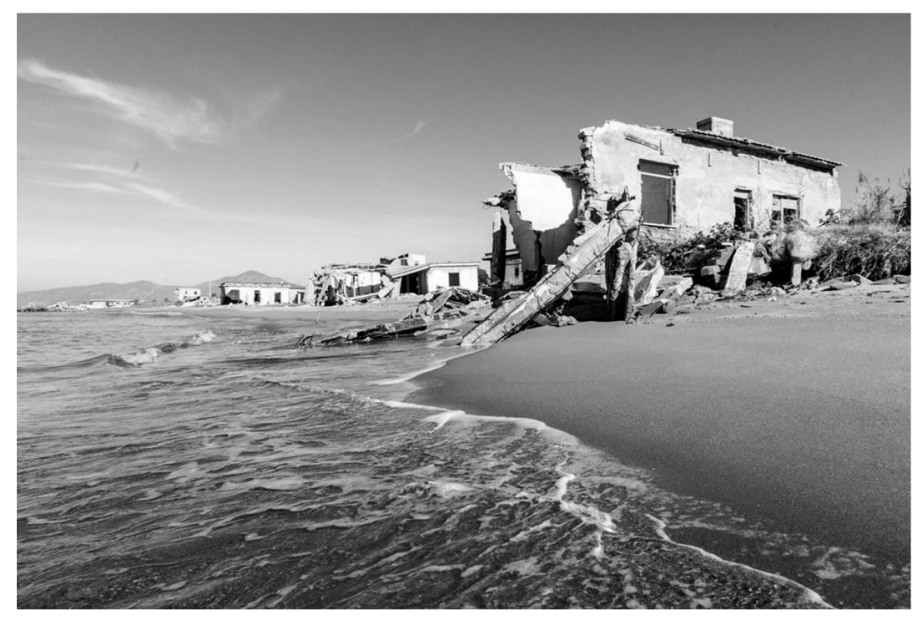

Figure 9. Bagnara beach in Castel Volturno in 2016 (www.internazionale.it).

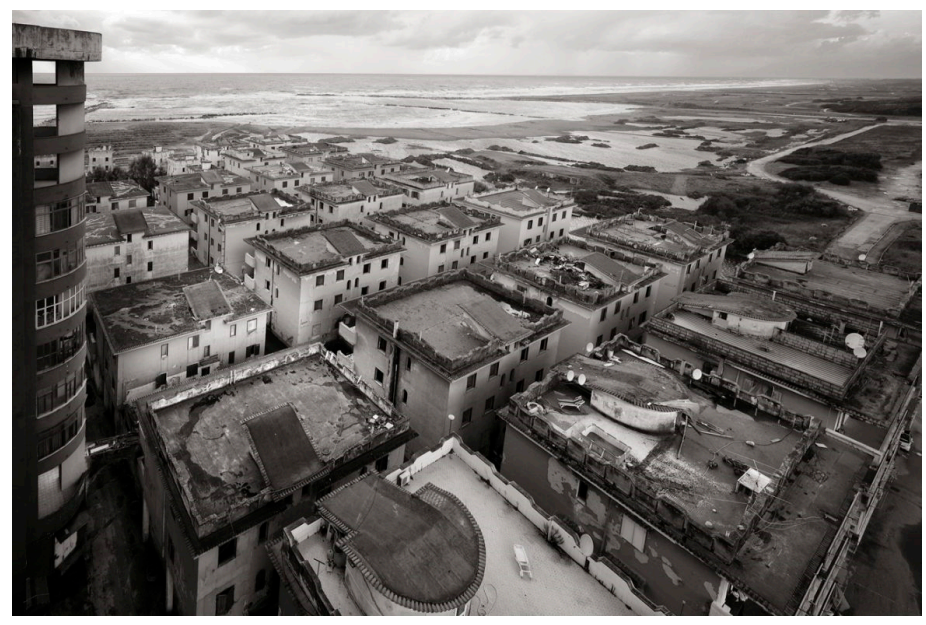

Figure 10. Aerial view of the coastline of Castel Volturno (www.livenet.it).

For these reasons, considering the specific knowledge of the authors about the territorial context of interest, the variable "immigrant population" can certainly be understood also as a "proxy" of the local economic-social conditions. 
This study represents the very early stage of the research on the relationship between housing prices and immigration, so it is not possible to say whether this correlation depends on the perception that the Italian natives population has of the migratory phenomenon, as is the case in the main Italian cities (in accordance with the study of Accetturo et al. [29]) for which a large immigrant population tends to reduce prices or, conversely, because the less spending power of the immigrant population implies that they focus on urban areas that are less well-liked due to poor location characteristics and more degraded buildings.

These questions leave room for further insights into future research on the topic, which, as the analysis has shown here, will become increasingly important on both a local and national level.

Acknowledgments: The article is part of the research project "Città interetnica e cittadinanza inclusiva: il caso della Campania" funding by Campania Region, Regional Law n.5/2002, and coordinated by Bianca Petrella, Department of Civil Construction and Environmental Engineering, University of Campania "Luigi Vanvitelli".

Author Contributions: This paper is to be attributed in equal parts to the authors.

Conflicts of Interest: The authors declare no conflict of interest.

\section{References}

1. Del Giudice, V.; De Paola, P.; Forte, F. Using Genetic Algorithms for Real Estate Appraisal. Buildings 2017, 7, 31. [CrossRef]

2. Del Giudice, V.; De Paola, P.; Forte, F. Bayesian neural network models in the appraisal of real estate properties. In Proceedings of the 2017 17th International Conference Computational Science and Its Applications (ICCSA), Trieste, Italy, 3-6 July 2017; pp. 278-489. [CrossRef]

3. Del Giudice, V.; De Paola, P.; Forte, F. The appraisal of office towers in bilateral monopoly's market: Evidence from application of Newton's physical laws to the Directional Centre of Naples. Int. J. Appl. Eng. Res. 2016, 11, 9455-9459.

4. Bengtsson, B. Housing as a Social Right: Implications for Welfare State Theory. Scand. Political Stud. 2001, 24, 255-275. [CrossRef]

5. King, P. Housing as a Freedom Right. Hous. Stud. 2010, 18, 661-672. [CrossRef]

6. Hohmann, J. The Right to Housing: Law, Concepts, Possibilities; Hart Publishing: Oxford, UK; Portland, OR, USA, 2013.

7. Forte, F.; Russo, Y. Evaluation of User Satisfaction in Public Residential Housing-A Case Study in the Outskirts of Naples, Italy. In Proceedings of the IOP Conference Series: Material Sciences and Engineering, World Multidisciplinary Civil Engineering-Architecture-Urban Planning Symposium (WMCAUS), Prague, Czech Republic, 12-16 June 2017; Volume 245.

8. CGL-Sunia. Abitare Per Gli Stranieri. 2016. Available online: http://old.cgil.it/Archivio/Welfare/Politiche_ abitative/Guida\%20_Abitare\%20per\%20gli\%20stranieri_.pdf (accessed on 28 January 2018).

9. Antoniucci, V.; Marella, G. Housing price gradient and immigrant population: Data from the Italian real estate market. Data Brief 2018, 16, 794-798. [CrossRef] [PubMed]

10. Ammirato, F.; Diana, P.; Strozza, S. Le soluzioni abitative. In Gli Immigrati in Campania Negli Anni Della Crisi Economica; De Filippo, E., Strozza, S.E., Eds.; FrancoAngeli: Milan, Italy, 2015.

11. Agenzia delle Entrate (OMI). Rapporto Immobiliare; Il Settore Residenziale, Agenzia delle Entrate: Roma, Italy, 2016.

12. Scenari Immobiliari. Immigrati e Casa; Rapporto 2016; Scenari Immobiliari: Roma, Italy, 2016.

13. IDOS. Dossier Statistico Immigrazione 2016; IDOS: Roma, Italy, 2016.

14. CIRDI. La Discriminazione Nell'accesso All'alloggio; Analisi Dei Settori Pubblico e Privato: Presidenza del Consiglio dei Ministri. Dipartimento per le Pari Opportunità: Roma, Italy, 2015.

15. Cristaldi, F. Immigrazione e Territorio: La Segregazione Residenziale Nelle Aree Metropolitane. Geotema 2012, 43-45, 17-28.

16. Baldini, M.; Federici, M. Non si Affitta Agli Immigrati. 2010. Available online: http://www.lavoce.info/ archives/26422/non-si-affitta-agli-immigrati/ (accessed on 28 January 2018).

17. Arbaci, S.; Malheiros, J. De-segregation, peripheralisation and the social exclusion of immigrants: Southern European cities in the 1990s. J. Ethn. Migr. Stud. 2010, 36, 227-255. [CrossRef] 
18. Arapoglou, V.P.; Sayas, J. New Facets of Urban Segregation in Southern Europe. Eur. Urban Reg. Stud. 2009, 16, 345-362. [CrossRef]

19. Tammaru, T.; Magnus, S.; Van, H.M.; Alexander, M.D. Relations between residential and workplace segregation among newly arrived immigrant men and women. Cities 2016, 59, 131-138. [CrossRef]

20. Antoniucci, V.; Marella, G. Small Town resilience: Housing market crisis and urban density in Italy. Land Use Policy 2016, 59, 580-588. [CrossRef]

21. Glaeser, E.L.; Resseger, M.; Tobio, K. Inequality in cities. J. Reg. Sci. 2009, 494, 617-646. [CrossRef]

22. Glaeser, E.L.; Kahn, M.E. Sprawl and urban growth. In Handbook of Regional and Urban Economics; Henderson, J.V., Thiesse, J.F., Eds.; Elsevier: Amsterdam, The Netherlands, 2004; Volume 4.

23. Wheeler, C.H. Urban Decentralization and Income Inequality: Is Sprawl Associated with Rising Income Segregation Across Neighborhoods? Federal Reserve Bank of St. Louis Regional Economic Development: St. Louis, MS, USA, 2006; Volume 4, pp. 41-57. [CrossRef]

24. Ewing, R.; Hamidi, S.; Grace, J.B.; Wei, Y.D. Does urban sprawl hold down upward mobility? Landsc. Urban Plan. 2016, 148, 80-88. [CrossRef]

25. Saiz, A. Immigration and housing rents in American cities. J. Urban Econ. 2007, 61, 345-371. [CrossRef]

26. Gonzalez, L.; Ortega, F. Immigration and housing booms: Evidence from Spain. J. Reg. Sci. 2013, 53, 37-59. [CrossRef]

27. Degen, K.; Fischer, A.M. Immigration and Swiss House Prices (November 2009). CEPR Discussion Paper No. DP7583. Available online: https:/ / ssrn.com/abstract=1533188 (accessed on 28 January 2018).

28. Sà, F. Immigration and Housing prices in UK. Econ. J. 2014, 125, 1393-1424. [CrossRef]

29. Accetturo, A.; Manaresi, F.; Mocetti, S.; Olivieri, E. Don't Stand So Close to Me: The Urban Impact of the Immigration (L'effetto Dell'immigrazione Nelle Città Italiane); Tema di Discussione n. 866, April 2012, Sommario Non Tecnico; Banca d'Italia: Roma, Italy, 2012.

30. Antoniucci, V.; Marella, G. Is social polarization related to urban density? Evidence from the Italian housing market. Landsc. Urban Plan. 2017. [CrossRef]

31. Antoniucci, V.; Marella, G. Immigrants and the city: The Relevance of Immigration on Housing Price Gradient. Buildings 2017, 7, 91. [CrossRef]

32. D'italia, B. Economie Regionali. L'economia della Campania; Banca d'Italia: Roma, Italy, 2016.

33. Agenzia delle Entrate (OMI). Nota Territoriale. Napoli. Andamento del Mercato Immobiliare nel I Semestre 2016, Settore Residenziale; OMI: Roma, Italy, 2016.

34. Del Giudice, V.; De Paola, P.; Manganelli, B.; Forte, F. The monetary valuation of environmental externalities through the analysis of real estate prices. Sustainability 2017, 9, 229. [CrossRef]

35. Solo Affitti-Nomisma. Rapporto Sulle Locazioni 2015; Solo Affitti: Roma, Italy, 2016.

36. Alisei Cooperativa Sociale. Sotto la Soglia. Indagine Conoscitiva Sul Disagio Abitativo Degli Immigrati Presenti Nell'italia Meridionale. 2008. Available online: http://briguglio.asgi.it/immigrazione-e-asilo/ 2008/novembre/rapp-alisei-abitazione.pdf (accessed on 28 January 2018).

37. Somma, S. Unauthorized Neighborhoods: A Recovery Proposal. Villaggio Coppola. Master's Thesis, University of Campania “Luigi Vanvitelli", Caserta, Italy, 2016.

38. Forte, F.; Granata, M.F.; Nesticò, A. A prioritisation model aiding for the solution of illegal buildings problem. In Lecture Notes in Computer Science; Springer: Cham, Switzerland, 2016; Volume 9786, pp. 193-206.

39. Mosca, L. Castel Volturno, un Pezzo d'Africa D'italia. Zapruder 2012, 28, 84-95.

40. Praesidium, V. Rapporto Sulla Situazione dei Migranti Presenti Nella Provincia di Caserta e Nell'area di Castel Volturno, Gennaio Aprile 2010; OIM—Organizzazione Internazionale per le Migrazioni: Roma, Italy, 2010.

41. Canesi, R.; Antoniucci, V.; Marella, G. Impact of socio-economic variables on property construction cost: Evidence from Italy. Int. J. Appl. Bus. Econ. Res. 2016, 14, 9407-9420.

42. Mangialardo, A.; Micelli, E. Simulation models to evaluate the value creation of the grass-roots participation in the enhancement of public real-estate assets with evidence from Italy. Buildings 2017, 7, 100. [CrossRef]

43. Antoniucci, V.; Marella, G. The influence of building typology on the economic feasibility of urban developments. Int. J. Appl. Eng. Res. 2017, 12, 4946-4954.

44. Antoniucci, V.; Marella, G. Torri incompiute: I costi di produzione della rigenerazione urbana in contesti ad alta densità. Sci. Reg. 2014, 13, 117-124. [CrossRef] 
45. Del Giudice, V.; De Paola, P. Spatial analysis of residential real estate rental market in Geoadditive Models. In Advances in Automated Valuation Modeling; D'Amato, M., Kauko, T., Eds.; Studies in System, Decision and Control; Springer: Cham, Switzerland, 2017; Volume 86, pp. 155-162.

46. Del Giudice, V.; Manganelli, B.; De Paola, P. Hedonic analysis of housing sales prices with semiparametric methods. Int. J. Agric. Environ. Inf. Syst. 2017, 8, 65-77. [CrossRef]

47. Del Giudice, V.; De Paola, P.; Forte, F.; Manganelli, B. Real Estate Appraisals with Bayesian Approach and Markov Chain Hybrid Monte Carlo Method: An Application to a Central Urban Area of Naples. Sustainability 2017, 9, 2138. [CrossRef]

48. Case, K.E.; Shiller, R.J.; Thompson, A. What Have They Been Thinking? Home Buyer Behavior in Hot and Cold Markets. Available online: http:/ / citeseerx.ist.psu.edu/viewdoc/download?doi=10.1.1.258.8835\& rep=rep1\&type=pdf (accessed on 28 January 2018).

49. Saaty, T.L.; De Paola, P. Rethinking Design and Urban Planning for the Cities of the Future. Buildings 2017, 7, 76. [CrossRef]

50. Moroni, S.; Antoniucci, V.; Bisello, A. Energy Sprawl, land taking and distributed generation: Toward a multi-layered density. Energy Policy 2016, 98, 266-273. [CrossRef]

51. Antoniucci, V.; D'Alpaos, C.; Marella, G. Energy saving in tall buildings: From urban planning regulation to smart grid building solutions. Int. J. Hous. Sci. Appl. 2015, 39, 101-110.

(c) 2018 by the authors. Licensee MDPI, Basel, Switzerland. This article is an open access article distributed under the terms and conditions of the Creative Commons Attribution (CC BY) license (http://creativecommons.org/licenses/by/4.0/). 